\title{
Lumen
}

Selected Proceedings from the Canadian Society for Eighteenth-Century Studies

\section{The French Salon of the Old Regime as a Spectacle}

\section{Jolanta T. Pekacz}

Volume 22, 2003

URI : https://id.erudit.org/iderudit/1012260ar

DOI : https://doi.org/10.7202/1012260ar

Aller au sommaire du numéro

Éditeur(s)

Canadian Society for Eighteenth-Century Studies / Société canadienne d'étude du dix-huitième siècle

ISSN

1209-3696 (imprimé)

1927-8284 (numérique)

Découvrir la revue

Citer cet article

Pekacz, J. T. (2003). The French Salon of the Old Regime as a Spectacle. Lumen, 22, 83-102. https://doi.org/10.7202/1012260ar

Copyright (c) Canadian Society for Eighteenth-Century Studies / Sociéte canadienne d'étude du dix-huitième siècle, 2003
Ce document est protégé par la loi sur le droit d'auteur. L'utilisation des services d'Érudit (y compris la reproduction) est assujettie à sa politique d'utilisation que vous pouvez consulter en ligne.

https://apropos.erudit.org/fr/usagers/politique-dutilisation/ 


\section{The French Salon of the Old Regime as a Spectacle}

The social life of the seventeenth-century French elite can be compared to a theatre where men and women, young and old, constructed their identities in terms of role-playing through the adoption and practice of a prescribed 'role.' Theatricality was thus fundamental to the seventeenth-century elite's self-fashioning that consisted in adopting and observing characteristic forms of behaviour, gestures and codes, considered appropriate for an individual according to his or her social position, sex, age, marital status, and circumstances. ${ }^{1}$ Theatricality of social life was grounded in the existence of a shared concept of mondanité - a system of social conventions that each member of the elite understood, that shaped the individual consciousness and valorized certain types of behaviour, and the existence of a public whose sensibility was formed by a common experience of elite sociability. Seventeenth-century mondanité was a concept embracing and relating all individual forms of social experience into a homogeneous and monolithic system of values and rules. Although the metaphor 'all the world's a stage' was not a seventeenth-century invention, it became a central metaphor of the century. ${ }^{2}$

The recourse to theatre and role-playing, the figure of an actor, and the tendency to construe the self in theatrical terms was not taken up voluntarily. Rather, it was for the French social elite a way of adapting to the new realities of political and social life in the period following the end of the French wars of religion, when traditional noble values began to wane

Research on this article was completed with the help of a Standard Research Grant from the Social Sciences and Humanities Research Council of Canada. I wish to thank Lorna Turcotte, Library Assistant in Reference Services, Mills Memorial Library, McMaster University, for bibliographical help.

1 I use the term 'theatricality' in this article to denote conscious fashioning of one's behaviour for the purpose of producing a particular effect and leaving little to spontaneity; an intentional grafting of theatrical elements into 'real life.' About theatricality in seventeenth-century France see, for example, Ziad Elmarsafy, The Hstrionic Sensibility: Theatricality and Identity from Corneille to Rousseau (Tübingen: G. Narr, 2001).

2 See Michel de Montaigne, Essais (1595). 
as the newly ennobled entered the ranks of the French nobility and when French nobles lost their battle over the control of the monarchy in the Fronde rebellion of 1648-1653. In response to these changes, in the course of the seventeenth century French authors in numerous treatises elaborated an ideal of social conduct (honnetteté) regulating the relationships between groups and individuals which made it possible for a hierarchical and heterogeneous society to function. ${ }^{3}$ This public system of values and rules comprised prescriptions pertaining to every aspect of an individual's existence, from the rules of bodily carriage, gesture, and facial expressions to intellectual and ethical formation. While cultivating the art of social performance was a way of leveling the differences between the members of various noble ranks - as well as to some extent between the nobles and the commoners - it also inevitably reinforced the existing social distances and created new ones. For one, one's place in social exchange was allocated according to one's social rank; secondly, the elaborate system of rules of social comportment, both written and unwritten, effectively sorted out those who could apply these rules with ease from those who merely imitated them, and gave a privileged position to the former. For La Rochefoucauld (1613-1680), refined social performance was as subtle and as difficult to achieve as perfect musicality was for the instrumentalist. ${ }^{4}$

The theatricality of social life in seventeenth-century France, the elite's preoccupation with itself, and obsession with style were captured in a literary genre that originated at that time - the novel of worldliness - epitomized by Mme de Lafayette's La Princesse de Clèves (1678) and continued in the eighteenth century by writers such as Crébillon, Duclos, Marivaux, and Laclos. ${ }^{5}$ Seventeenth-century art representing

3 For example, Claude Favre de Vaugelas, Remarques sur la langue française (Paris: A. Curbi, 1647), 476-477; Antoine Gombaud, chevalier de Méré, Lettres, 2 vols. (Paris: Denis et Barbin, 1689), I, 55-58; Abbé Goussault, Réflexions sur les défauts ordinaires des hommes et sur leurs bonnes qualitez (Paris: chez la veuve M. Guerout, 1692), 267-272; Nicolas Faret, L'Honnête Homme (1630), reprinted several times before 1650; Jacques Du Bosc, L'Honneste Femme, 3 vols. (Paris, 1632-1636); François de Grenaille, L'Honneste Fille, 3 vols. (Paris: Jean Paslé, 1639-1642); L'Honneste Veuve (Paris: Quinet, 1640); L[ouis] Couvay, L'Honneste Maitresse (Paris: chez Guillaume de Luyne, 1654); Charles Sorel, Discours pour et contre l'amitié tendre hors du mariage (1663); anonymous, Amelonde, histoire de nostre temps ou l'on voit qu'une honneste femme est heureuse quand elle suit un conseil sage et verteux (1669).

4 François de La Rochefoucauld, CEuvres complètes (Paris: Gallimard, 1964), 506.

5 See, for example, Peter Brooks, The Novel of Worldliness: Crébillon, Marivaux, Laclos, Stendhal (Princeton: Princeton University Press, 1969). 
social performance, epitomized by paintings and drawings by Antoine Watteau (1684-1721), provides a pictorial counterpart to this literature. ${ }^{6}$

The relationship between the sexes occupied a prominent place in the works by moralists and fiction writers; both men and women were expected to play their social roles by adhering to elaborated rules of bienséances appropriate for each sex, and to observe gender division of the spheres of activity and occupation. Seventeenth-century writers on honnêteté emphasized an important role of some upper-class women in the civilizing process including preserving and disseminating the ideal of politeness, good manners, and propriety inherent in honnêteté. Although women's superior intuition was one characteristic that made such a role possible, the belief in the civilizing role of women was not rooted in some essential female characteristics and therefore was not extended to all women. The civilizing role of a woman was a function of her class and of her conduct - not all upper-class women were considered authorities on propriety, only those with an impeccable record of adhering to the prescribed ideal of feminine propriety. The writers on honnêteté clearly differentiated between two categories of upper-class women: honnêtes, whose influence was considered beneficial for the civilizing process, especially for the formation of young men and women, and their opposite - coquettes, savantes and libertine women - whose influence was detrimental and whose company should be avoided. ${ }^{8}$

6 See, for example, Mary Vidal, Watteau's Painted Conversations: Art, Literature and Talk in Seventeenth and Eighteenth-Century France (New Haven and London: Yale University Press, 1992); Thomas E. Crow, Painters and Public Life in Eighteenth-Century Paris (New Haven: Yale University Press, 1985); Sarah R. Cohen, Art, Dance, and the Body in French Culture of the Ancien Régime (Cambridge: Cambridge University Press, 2000).

7 I discuss these issues in detail in my Conservative Tradition in Pre-Revolutionary France: Parisian Salon Women (New York: Peter Lang, 1999), especially in chapters I and II.

8 For example, Morvan de Bellegarde, Modèles de conversations pour les personnes polies (1697) 4th ed. (Amsterdam: chez Henri Schelte, 1702), 222-237. In a similar vein David Hume praised the beneficial influence of women in the mid-eighteenth century: 'What better school for manners than the company of virtuous women, where the mutual endeavour to please must insensibly polish the mind, where the example of the female softness and modesty must communicate itself to their admirers, where the delicacy of that sex puts every one on his guard, lest he give offence by any breach of decency?' 'Of the Rise and Progress of the Arts and Sciences,' in Essays and Treatises on Several Subjects, 2 vols. (Edinburgh: Bell and Bradfute, 1804), I, 138. 
The recognition of the civilizing role of honnettes women made the salon possible. ${ }^{9}$ The salon emerged as a form of sociability which allowed for a regular interaction between men and women of various social ranks and occupations, took place outside the royal court, typically involved conversation and sometimes also other forms of entertainment, and was hosted by an upper-class lady in her house. Thus the salon created a unique opportunity for some upper-class women to function outside the strictly domestic sphere, traditionally designated for women, without violating traditional feminine social roles. Seventeenth-century writers commonly held that salons played an important role in the implementation of the principles of honnêteté..$^{10}$

As hosting a salon meant performing a specific role within a strictly delineated social convention, theatricality - a conscious fashioning of one's behaviour in order to enact a specific social role - was an inherent characteristic of salons, just as it was inseparable from Old-Regime polite society as a whole. It can be argued that theatricality was the very characteristic of social life that made the salon in France possible in the early seventeenth century for it allowed women to host social gatherings without violating the gender status quo; in fact, it reinforced this status quo. But theatricality was also one of the reasons why salons came under attack in the course of the eighteenth century, along with polite society and mondanité. In the rest of this article, I explore the theatricality of salons and the changing valorization of this quality in Old-Regime France. I argue that the criticism of salons that mounted in the second half of the eighteenth century was not a misogynist reaction of some of the members of the Republic of Letters against an allegedly excessive public presence of salon women and the alleged 'masculinization' of the public sphere, but rather a result of a wider process of reformulation of the parameters of sociability, which involved changing the valorization of qualities such as artifice, politeness, and

9 Although I use salon throughout this article, the term salon in its present-day sense, that is, as a metonymy for social gathering, came into usage only in the nineteenth century. What in the nineteenth century came to be called salon, in the seventeenth century was referred to as ruelle, cabale, cabinet, réduit, alcôve, compagnie, société, cour littéraire, cercle, assemblée and chambres; and in the eighteenth century souper, diner, or bureau d'esprit.

10 See, for example, Antoine de Gombaud, chevalier de Méré, CEuvres complètes, 3 vols. (Paris: Fernand Roches, 1930), III, 75; De Chalesme, L'Homme de qualité, ou les moyens de vivre en homme de bien et en homme du monde (Amsterdam, 1671), 197; Nicolas Faret, L'Honnête Homme, ou l'Art de plaire à la cour (1630) (Genève: Slatkine Reprints, 1970), 89 and 95-96. 
mondanité, and the quest for individualism, authenticity, naturalness, and perfect communication. ${ }^{11}$

As part of polite society, salons belonged to the social milieu closed to the outside world but utterly public to its members. Salons were described in detail in memoirs and letters by those who visited them; they were also referred to by those who only heard about them. And because letters by public figures often circulated in a wider circle of polite society, such descriptions further amplified the internal publicity of the salon and made the question of right social conduct vital. This internal publicity made the salon a theater, a stage for the individual's representations of his or her social life, and elicited a conception of an individual as a voluntary artistic self-creation whose social style was the most important fact about him. Eut the essence of salon theatricality was that each participant performed a socially prescribed role; that is, the individual was expected to incarnate characteristics considered appropriate for his or her social position, gender, age, marital status, and circumstances. In the case of salon hostesses, it was thus of vital importance that they stayed within the social convention prescribed for women of their rank and status.

Numerous descriptions of Old-Regime Parisian salons left by some of their guests testify that from the early seventeenth century, salon hostesses were viewed and commented upon in terms of the criteria of traditional feminine propriety. Salon hostesses who did not conform to the prescribed social norm were immediately spotted and ridiculed by men and women alike. Seventeenth-century précieuses provide the most spectacular case of feminine transgression of propriety and the subversion of the accepted theatricality of social life. ${ }^{12}$ Rather than playing the

11 The works dealing with various aspects of this process include Michael Fried, Absorption and Theatricality, Painting and Beholder in the Age of Diderot (Chicago: University of Chicago Press, 1980); Cohen, Art, Dance, and the Body; Sophia Rosenfeld, A Revolution in Language. The Problem of Signs in Late Eighteenth-Century France (Stanford: Stanford University Press, 2001); Colin Jones and Dror Wahrman (eds.), The Age of Cultural Revolutions. Britain and France, 1750-1820 (Berkeley: University of California Press, 2002); Paul Friedland, Political Actors: Representative Bodies and Theatricality in the Age of the French Revolution (Ithaca: Cornell University Press, 2002).

12 I use the term précieuse and its derivatives in a specific meaning, as originally coined in the early 1650 s, to ridicule the affectation of feminine mondaine coteries between 1650 and 1660. The term is also used in a broader and neutral meaning. See, for example, Antoine Adam, Littérature française. L'âge classique. I: 1624-1660 (Paris: 
prescribed feminine roles, précieuses fashioned themselves in a way that turned society's role-playing upside-down. In contrast to the salons of honnettes ladies, epitomized by the salon of the marquise de Rambouillet (1588-1665), the précieuses of the mid-seventeenth century were accused of trying to distinguish themselves deliberately from the rest of polite society by cultivating over-sophisticated manners within the circle of the habitués of their salons. ${ }^{13}$ Thus, their behaviour violated the principle of conformity inherent in honnêteté. Their conversation, too, violated the rules of polite conversation in that the précieuses went too far in the sublimation of the language and turned it into incomprehensible jargon. ${ }^{14}$ The précieuses' ambitions to literary arbitration violated the gender status quo, as in the mid-seventeenth century it was still primarily the domain of men to issue opinions in literary matters. Women could occasionally venture into this domain if they confined themselves to the rules of propriety; ${ }^{15}$ it was not the judgement of coquettes that literary men were looking for. ${ }^{16}$ Criticism of the précieuses was further fuelled by their rejection of traditional women's roles of wives and mothers expected from honnettes women by seventeenth-century society. This could lead to the violation of the existing social and moral order, and disturb the traditional relationships between the sexes. By rebelling against the traditional idea of marriage, the précieuses rebelled against the existing gender status quo. Préciosité became an ambiguous notion associated, on the one hand, with wit, politeness, urbanity, sophistication, femininity, and gallantry, but on the other, with excessive affectation of manners,

Arthaud, 1968), 44 and Carolyn C. Lougee, Le Paradis des femmes. Women, Salons, and Social Stratification in Seventeenth-Century France (Princeton, New Jersey: Princeton University Press, 1976), 7.

13 See Michel de Pure, La Prétieuse; ou, le Mystère des Ruelles (Paris, 1656-57), edited by Émile Magne, 2 vols. (Paris: Librairie Droz, 1938-1939), I, 58; see also Noémi Hepp, 'La notion d'hérö̈ne,' Onze études sur l'image de la femme dans la littérature française du dix-septième siècle, 2nd ed., ed. Wolfgang Leiner (Tübingen: Günter Narr Verlag, Paris: Éditions Jean-Michel Place, 1984), 21.

14 André Pessel, 'De la conversation chez les précieuses,' Communications: La Conversation (Paris: Seuil, 1979), 14-30.

15 See, for example, Grenaille, L'Honneste Fille, III, 77-79.

16 '... comme ie n'ay trauaillé qu'en faueur des honnestes femmes, ie serois bien marry d'auoir l'approbation des Coquettes ... mon liure seroit bien mauuais, si elles en faissoient vn bon iugement.' Grenaille, La Bibliothèque des dames (Paris: Anthoine de Sommaville, 1640), as quoted in Ian Maclean, Woman Triumphant. Feminism in French Literature, 1610-1652 (Oxford: Clarendon Press, 1977), 149. 
pretentiousness, incomprehensible jargon, luxury, illicit love, intrigues, coteries, and rebellion against restrictions imposed on women by the traditional society. ${ }^{17}$ And just as in dramatic convention the reversal of roles typically belonged to the genre of comedy and was used to create a temporary 'aberration' which inevitably resolved itself by returning to the 'normal' state of affairs, in real life the self-fashioning of the précieuses was spotted as an 'aberration' of the theatricality of social life and ridiculed.

As with their seventeenth-century predecessors, eighteenth-century salon hostesses and their guests were also expected to satisfy the conventions of social theatricality. Mme du Deffand (1697-1780) considered Mme Necker (1739-1794) cold and full of amour-propre, ${ }^{18}$ and the tone of her salon much too elevated by the standards of polite society. ${ }^{19}$ Other guests of Mme Necker's shared this opinion. ${ }^{20}$ The baroness d'Oberkirch (1754-1803), too, left an unfavourable picture of Mme Necker precisely because she failed to perform up to the standards of mondaine theatricality:

En dépit des grandes positions qu'elle a occupées, c'est une institutrice, et rien de plus. Elle est pédante et prétentieuse au delà de tout. ... elle a reçu une excellente éducation, dont elle profite par le travers. ... [mais] Elle n'aura jamais l'art de plaire. Pour tout dire en un mot, elle ne sait ni pleurer ni sourire. ${ }^{21}$

The theatricality of the salon was first and foremost embodied in polite conversation, considered a superior mode of communication in polite society and the raison d'etre of the salon. ${ }^{22}$ Conversation was

17 See Roger Lathuillère, La Préciosité. Étude historique et linguistique, vol. I (Genève: Librairie Droz, 1966), 30-60.

18 Letter to Horace Walpole, 5 May, 1776, in Horace Walpole's Correspondence with Madame Du Deffand and Wiart, 6 vols. (New Haven: Yale University Press, 1939-1970), VI (IV), 310.

19 '[Elle] a de l'esprit, mais il est d'une sphère trop élevée pour que l'on puisse communiquer avec elle.' Letter to Horace Walpole, 9 June, 1776, ibid., 327.

20 For example, Jean-François Marmontel wrote: 'J'affectais d'opposer mes idées simples et vulgaires à ses hauteurs inaccessibles pour communiquer avec moi.' See S. Lenel, Un homme de lettres au XVIII' siècle: Marmontel d'après des documents nouveaux et inédits (Paris, 1902, Genève: Slatkine, 1970), 41.

21 Mémoires de la baronne d'Oberkirch sur la cour de Louis XVI et de la société française avant 1789, ed. Suzanne Burkard (Paris: Mercure de France, 1970), 190.

22 About the role of conversation in self-fashioning of seventeenth-century French elite, 
regulated by sophisticated rules elaborated by numerous seventeenthand eighteenth-century authors, ${ }^{23}$ and the precepts for polite conversation did not change much throughout the Old Regime. In tune with the seventeenth-century rules, the abbé Morellet (1727-1819) believed that a perfect conversation was the incarnation of the principle of juste milieu: it should be neither 'rigorously methodical,' because it became heavy and pedantic; nor should it be 'entirely rambling,' because it then became frivolous and ridiculous. ${ }^{24}$ Further, conversation was supposed to be general rather than specific, so that no specialized knowledge was required and all could participate. ${ }^{25}$ For seventeenth-century theoreticians of honnêteté, a specific conversation was typical of pedants and savants, not of polite society. Jean Chapelain (1595-1674), littérateur and a frequent guest in seventeenth-century salons, contrasted the pedantry and pretentiousness of the salon of the vicomtesse d'Auchy (ca. 15701646) with the good sense and juste milieu of that of the marquise de Rambouillet. As opposed to the salon of the vicomtesse, wrote

see, for example, Elizabeth C. Goldsmith, introduction to 'Exclusive Conversations.' The Art of Interaction in Seventeenth-Century France (Philadelphia: University of Pennsylvania Press, 1988), 1-15.

23 For example, René Bary, L'Esprit de cour, ou, Les conversations galantes, divisées en cent dialogues (Paris: Charles de Sercy, 1662); Gabriel de Bremond, Le Cercle; ou, Conversations galantes (Paris: n.p., 1673); Madeleine de Scudéry, Conversations sur divers sujets, 2 vols. (Paris: chez Claude Barbin, au Palais, sur le Perron de la Sainte Chapelle, 1680), Conversations morales, 2 vols. (Paris: sur le Quay des Augustins, 1686); Jean-Baptiste Morvan de Bellegarde, Modèles de conversation pour les personnes polies (1697), $4^{\text {th }}$ ed. (Amsterdam: chez Henri Schelte, 1702); Augustin Pons Alletz, Manuel de l'homme du monde ou Connoissance generale des principaux etats de la société, E de toutes les matières qui font le sujet des conversations ordinaires ... par ordre alphabetique (Paris: Chez Guillyn, 1761); Nicolas-Charles-Joseph Trublet, 'Pensées sur la conversation,' in Mercure de France, December, 1756, II, 16-33; January 1757, I, $36-55$ and II, 38-68; [Morellet], 'De la conversation,' in Éloges de Mme Geoffrin, contemporaine de Madame du Deffand, par MM. Morellet, Thomas et D'Alembert, suivis de lettres de Madame Geoffrin et à Madame Geoffrin et d'un Essay sur la conversation, etc. etc., par M. Morellet (Paris: H. Nicolle, 1812).

24 'Il y a donc un milieu entre ces deux extrémités, et la conversation ne doit être ni rigoureusement méthodique, ni absolument décousue. Dans le premier cas, elle devient pesante et pédantesque; dans la deuxième, elle est frivole et ridicule.' [Morellet], 'De la conversation,' in Éloges de Mme Geoffrin, 198.

25 'Participation' in a conversation did not necessarily mean for Morellet an active participation; listening was for him also participation. 'La conversation est générale lorsq'elle est entre toutes les personnes qui forment le cercle ou la société, et que chacun y contribue, soit comme acteur, soit comme auditeur.' [Morellet], 'De la conversation,' 216. 
Chapelain, 'On n'y parle point sçavament [chez la marquise], mais on y parle raisonnablement et il n'y a lieu au monde où il y ait plus de bon sens et moins de pédanterie. ... l'hostel de Ramb[ouillet] est l'antipathe de hostel d'Ochy. ${ }^{26}$ Salon hostesses were thus responsible for observing the boundaries between polite conversation and other forms of discourse, particularly learned discourse. A salon hostess was to incarnate feminine bienséances; a salon was not a place of learned discourse, but of polite conversation.

In addition to form, topics of polite conversation were also subject to careful scrutiny. Religion and politics in particular were to be treated with 'great circumspection' - along with other 'irritable topics' practically to the point of exclusion. ${ }^{27}$ And as polite conversation was to be a source of pleasure, too serious or extraordinary topics were not recommended either. ${ }^{28}$

The presence of women shaped both form and content of polite conversation in a distinctive way. A prolific author of works on honnêteté, Morvan de Bellegarde (1648-1734), believed that conversation with women required extra caution due to their sensitivity to the propriety of language and of manners.

[L]e moindre mot qu'on dit a leur [femmes] desavantage, et qu'elles interpretent toujours en mauvaise part, leur donne d'etranges inquietudes; ... la plupart de leurs conversations se passent en explications et en apologies, pour donner un bon sens a ce qu'on a dit. ${ }^{29}$

26 Chapelain to Balzac, 22 March, 1638, in Lettres de Jean Chapelain de l'Académie française, edited by $\mathrm{Ph}$. Thamizey de Larroque, 2 vols. (Paris: Imprimerie nationale, 1880-1883), I, 215-216; also Chapelain to Balzac, 7 April, 1638, ibid., I, 222.

27 See, for example, Madeleine de Scudéry, 'Contre ceux qui parlent peu respectueusement de la religion,' in Conversations sur divers sujets, 2 vols. (Paris: chez Claude Barbin, au Palais, sur le Perron de la Sainte Chapelle, 1680), I, 173-199; 'Contre ceux qui décrient le gouvernement, quel qu'il soit,' ibid., 251-270. I discuss the details of form and content of polite conversation in Chapter I of my Conservative Tradition in Pre-Revolutionary France: Parisian Salon Women, $70 \mathrm{ff}$.

28 '[L]es récits des choses funestes et extraordinaires ne plaisent pas' wrote Mlle de Scudéry in Conversations sur divers sujets, I, 27-28.

29 CEuvres diverses de M. l'abbé de Bellegarde, 4 vols. (Paris: C. Robustel, 1723), I: 'Les reflexions sur le ridicule et sur les moyens de l'eviter,' 321; Christoph Strosetzki, Rhétorique de la conversation: Sa dimension littéraire et linguistique dans la société française $d u$ XVII siècle, trans. from the German by Sabine Seubert. Papers on French Seventeenth-Century Literature, no. 20 (Paris-Seattle-Tübingen: Biblio 17, 1984), 73. 
Since conversation was supposed to be comprehensible and entertaining for women participating in it, topics had to be properly selected. According to Nicolas Faret (1596-1646), 'des femmes surtout ne doivent pas subir de la part d'un honnête homme l'ennui des récits militaires, des relations de chasse, les désagréments d'un comportement arrogant et de jurons. ${ }^{30}$ François de Grenaille (1616-1680) wrote in 1642 that ' [n]ous ne sommes pas dans le Porche n'y dans le Lycée, pour que nous sommes en compagnie de quelques Seigneurs ou de quelques Dames. ${ }^{31}$ Similarly, according to the Chevalier de Méré (1607-1684), one of the seventeenth-century authorities on honnêteté, the content of polite conversation had to be adapted to the presence of women; for example, it was inappropriate to be savant among the ladies. ${ }^{32}$

Consequently, salon guests were carefully selected to ensure harmony of opinions and not all men of letters and philosophes had access to feminine salons. For example, Denis Diderot (1713-1784), 'an extremely sociable man,' as his biographer writes, who loved to talk and for whom 'communication was almost a compulsion,' ${ }^{33}$ was excluded from the salon of Mme du Deffand because of the radicalism of his views. 'D'Alembert's rigid theorizing combined with a contempt for compromise' - wrote a present-day author - 'rendered him harmless whereas Diderot's passionate contradictory views constituted a threat to Madame du Deffand's unyielding conservatism. ${ }^{34}$

Mme Geoffrin (1699-1777) excluded Diderot from her salon, too, for similar reasons. According to an eighteenth-century author, she feared Diderot's impetuosity and the rashness of his opinions supported when he was aroused - by a fiery and stirring eloquence. ${ }^{35}$ In a letter to

30 Faret, L'Honnête Homme, 88.

31 François de Grenaille, La Mode ou Caractère de la religion, de la vie, de la conversation, de la solitude, des compliments, des habits, et du style du temps (Paris, 1642), 267, as quoted by Jean-Pierre Dens, 'L'art de la conversation au dix-septième siècle,' Les Lettres romanes $27 / 3$ (1973), 218.

32 Letter to the duchesse de Lesdiguières, in Lettres, (1682), 2 vols. (Paris: Par la Compagnie des Libraires, 1689), I, 32-33.

33 Arthur M. Wilson, Diderot (New York: Oxford University Press, 1972), 173.

34 Benedetta Craveri, Madame du Deffand and Her World, trans. from the Italian and the French by Teresa Waugh (Boston: David R. Godine, 1994), 130.

35 François-Louis, comte d'Escherny, Mélanges de littérature, d'histoire, de morale et de philosophie, 3 vols. (Paris, 1811), III, 128. Paradoxically, as noted by Arthur M. Wilson, the three anonymous pamphlets written by Diderot during the Querelle des Bouffons were characterized by the spirit of moderation and conciliation. Wilson, Diderot, 179. 
the Polish King, Stanislaw August Poniatowski (1732-1798), Mme Geoffrin described Diderot as 'upright,' but 'wrongheaded' and 'poorly organized. ${ }^{\prime 36}$ Excluded from a number of feminine salons, Diderot successfully practiced his conversational skills at the dinners of the baron d'Holbach.

Topics of salon conversations appear to have been as carefully selected as were salon guests. Mme Geoffrin was known for her circumspection in the way she allowed the conversation in her salon to proceed. In 1770, Frederick Melchior Grimm (1723-1807) reported that Mme Geoffrin re-imposed restriction on topics of conversations in her salon:

Mère Geoffrin fait savoir qu'elle renouvelle les défenses et lois prohibitives des années précédantes, et qu'il ne sera pas plus permis que par le passé de parler chez elle ni d'affaires intérieures, ni d'affaires extérieures; ni d'affaires de la cour, ni d'affaires de la ville; ni d'affaires du nord, ni d'affaires du midi; ni d'affaires d'Orient, et d'Occident; ni de politique, ni de finances; ni de paix, ni de guerre; ni de religion, ni de gouvernement; ni de théologie, ni de métaphysique; ni de grammaire, ni de musique; ni d'aucune matière quelconque. ${ }^{37}$

Antoine-Léonard Thomas (1732-1785) wrote that Mme Geoffrin was incapable of tolerating the tone of conversation that was not juste milieu. 'Tout ce qui était ardent autour d'elle l'exaspérait; elle craignait l'impétuosité des idées comme des sentiments et croyait que la raison même avait tort quand elle était passionnée. ${ }^{38}$ Mme Necker, concerned with proper decorum, carefully prepared conversations in her salon and went as far as to write detailed scripts for herself prior to each meeting to make sure that the right questions were addressed to the right people and that everyone was given attention, according to his position and rank (women were rarely guests in prominent Parisian salons of the eighteenth century). ${ }^{39}$

36 'C'est un bon et honnête homme, mais il a la tête si mauvaise, et il est si mal organisé, qu'il ne voit ni n'entend rien de ce qu'il voit, ni de ce qu'il entend, tel que cela est; il est toujours comme un homme qui rêve, et qui croit réel tout ce qu'il a rêvé.' Correspondance inédite du roi Stanislas-Auguste Poniatowski et de Madame Geoffrin (1764-1777), ed. Charles de Mouy (Paris, 1875; Genève: Slatkine Reprints, 1970), 466.

37 Frederick Melchior Grimm, Correspondance littéraire, philosophique et critique, 16 vols., ed. Maurice Tourneux (Paris: Garnier, 1877-1882), VIII, 438.

38 Antoine-Léonard Thomas, 'A la mémoire de Mme Geoffrin,' in Éloges de Madame Geoffrin, 83.

39 According to Marc Fumaroli, Mme de Genlis remembered chevalier de Chastellux finding in a salon of Mme Necker a notebook in which she wrote: 'Préparation du 
Consequently, the salon of Mme Necker received its own share of criticism from its habitués. ${ }^{40}$

Theatricality, role-playing and the lack of spontaneity of salons were in tune with seventeenth-century ideals of mondanité and social decorum but in the course of the eighteenth century these very qualities of social life began to be perceived as ambiguous. The tone of criticism appears in the descriptions of salons. It is no longer refined politeness and artifice but rather spontaneity and naturalness that become the most sought-after qualities of social life. The salon of Mme de Lambert (1647-1735) in the early eighteenth century was the first to be perceived as lacking in these qualities. A present-day author suggested that it was the formality of tone in the salon of Mme de Lambert and the restrictions she imposed upon conversation in her salon that made its habitual guests, writers Antoine Houdar de La Motte and Antoine Terrasson, seek a more relaxed atmosphere in the Parisian cafés, Gradot and Procope. ${ }^{41}$ JeanFrançois Marmontel (1723-1799), a faithful habitué of many eighteenth-century salons and not inimical to the culture of mondanité, was one of the most explicit critics of the theatricality of salons. According to Marmontel, in the salon of Mme de Tencin (1682-1749), theatricality bordered on farce:

on y arrivoit préparé à jouer son rôle, et. ... l'envie d'entrer en scène n'y laissoit pas toujours à la conversation la liberté de suivre son cours facile et naturel. C'était à qui saisiroit le plus vite, et comme à la volée, le moment de placer son mot, son conte, son anecdote, sa maxime où son trait léger et piquant, et pour amener l'à-propos, on le tiroit quelquefois d'un peu loin. Dans Marivaux, l'impatiance de faire preuve de finesse et de sagacité perçoit visiblement. Mon-

diner de ce soir: je parlerai au chevalier de Chastellux de la Félicité publique, et d'Agathe à Mme d'Angiviller sur l'amour.' L'Art de la conversation. Anthologie (Paris: Classiques Garnier, 1997), 349.

40 According to Morellet, 'La conversation y était bonne, quoique un peu contrainte par la sévérité de Mme Necker, auprès de laquelle beaucoup de sujets ne pouvaient être touchés, et qui souffrait surtout de la liberté des opinions religieuses. Mais, en matière de littérature, on causait agréablement, et elle en parlait elle-même fort bien.' André Morellet, Mémoires inédits de l'abbé Morellet. Sur le dix-huitième siècle et sur la Révolution, 2nd ed. 2 vols. (Paris, 1822; Gevève: Slatkine Reprints, 1967), I, 154.

41 Roger Marchal, Madame de Lambert et son milieu (Oxford: The Voltaire Foundation at the Taylor Institution, 1991) 241, n. 110. 
tesquieu, avec plus de calme, attendoit que la balle vint à lui, mais il attendoit. Mairan guettoit l'occasion. Asturc ne daignoit pas l'attendre. Fontenelle seul la laissoit venir sans la chercher, que ses mots fins, ses jolis contes n'occupoient jamais qu'un moment. Helvétius, attentif et discret, recueilloit pour semer un jour. $^{42}$

André Morellet (1727-1819), also a frequent guest at Parisian salons before the French Revolution, wrote in his memoirs that the atmosphere at Mme Geoffrin's was suffocating due to the hostess's extreme precaution with which she treated topics of conversation in her salon. In Morellet's view, Mme Geoffrin was

un peu méticuleuse et timide, obséquieuse envers le gouvernement, ménageant les gens en place et les gens de la cour: sentiments bien excusables et bien naturels dans une femme âgée, qui soignait avec raison sa vie, et ne voulait pas en compromettre la douceur et la tranquilité ... ${ }^{43}$

\section{Consequently, according to Marmontel,}

il manquoit à la société de Mme Geoffrin l'un des agrémens dont je faisois le plus de cas, la liberté de la pensée. Avec son doux voilà qui est bien, elle ne laissoit pas de tenir nos esprits comme à la lisière; et j'avois ailleurs des diners où l'on étoit plus à son aise. ${ }^{44}$

And just as La Motte and Terrasson made Parisian cafés an escape from the salon of Mme de Lambert, so did the guests of Mme Geoffrin who sought less restricted ways of socializing.

Après nos diners chez elle [Mme Geoffrin] nous nous rendions souvent aux Tuileries, d'Alembert, Helvétius, Galiani, Marmontel, Thomas, etc., pour y trouver d'autres amis, apprendre d'autres nouvelles, fronder le gouvernement et philosopher tout à notre aise. Nous faisions cercle, assis au pied d'un arbre de la grande allée, et nous abandonnant à une conversation animée et libre comme l'air que nous respirions. ${ }^{45}$

42 Jean-François Marmontel, Mémoires, ed. John Renwick, 2 vols. (Clermont-Ferrand: G. de Bussac, 1972), I, 101-102.

43 Morellet, Mémoires inédits I, 87.

44 Ibid., I, 170.

45 Ibid., I, 95-96. 
An alternative to the salons that cultivated the ideal of mondanité rooted in the seventeenth century were the dinners in the homes of two philosophes, Claude Adrien Helvétius (1715-1771) and the baron d'Holbach (1723-1789), both enjoying the reputation of places giving priority to intellectual discourse rather than to decorum without, however, violating commonly accepted rules of civility. Scottish philosopher David Hume (1711-1776) wrote from Paris that the men of letters he met at d'Holbach's were 'really very agreeable; all of them Men of the World, living in entire or almost entire Harmony among themselves, and quite irreproachable in their manners. ${ }^{46}$ Morellet was also impressed by the relaxed and friendly atmosphere at d'Holbach's dinners:

Une grosse chère, mais bonne, d'excellent vin, d'excellent café, beaucoup de disputes, jamais de querelles; la simplicité des manières, qui sied à des hommes raisonnables et instruits, mais qui ne dégénérait point en grossièreté; une gaité vraie, sans être folle ... ${ }^{47}$

Marmontel noted that men of letters felt more at ease at the dinners of $\mathrm{d}$ 'Holbach and Helvétius than in the salons run by women. ${ }^{48}$ It was there where Diderot and other philosophes excluded from the salons of the time indulged in intellectual exchange uninhibited by the limits of mondanité. Morellet emphasized that it was not at the salon of Mme Geoffrin or Mlle de Lespinasse but at the dinners of d'Holbach where one could hear

la conversation la plus libre, la plus animée et la plus instructive qui fût jamais: quand je dis libre, j'entends en matière de philosophie, de religion, de gouvernement, car les plaisanteries libres dans un autre genre en étaient bannies.... il n'y a point de hardiesse politique et religieuse qui ne fût là mise en avant et discutée pro et contra, presque toujours avec beaucoup de subtilité et de profondeur. ${ }^{49}$

Diderot, too, testified that only at d'Holbach's dinners could one enjoy an uncensored and intellectually satisfying conversation. ${ }^{50}$ In contrast to the salons, it was not the propriety of conversation that was given

46 David Hume to the Rev. Hugh Blair, [Paris?], December, 1763, Letters of David Hume, ed. J.Y.T. Greig, 2 vols. (Oxford: Clarendon Press, 1969), I, 419.

47 Morellet, Mémoires inédits, I, 133; see also Marmontel, Mémoires, I, 312.

48 Marmontel, Mémoires, I, 227.

49 Ibid., I, 133-134.

50 CEuvres complètes de Diderot, 20 vols. (Paris: Garnier Frères, 1875-1876), X, 379. 
priority but its content. This is why religion - excluded from salons could become a favourite topic at d'Holbach's dinners. ${ }^{51}$

The difference between the dinners of $\mathrm{d}^{\prime} \mathrm{Holbach}$ and the salons rooted in the seventeenth-century tradition of mondanité was captured by salonnière Mme du Deffand in a letter she wrote in 1765 to Georges Selwin, an old school fellow of Horace Walpole (1717-1797). The dinners of d'Holbach were not to Mme du Deffand's liking precisely because they were the antithesis of the tradition of mondanité.

Je vais quelquefois chez le baron d'Holbach; mais j'ai planté là ses dîners; c'était à n'y pas tenir avec ses auteurs, ses philosophes et ses savants dont il a toujours un plein pigeonnier. Ils m'avaient fait tourner la tête avec un nouveau système de déluges antédiluviens qu'ils ont inventé pour prouver l'éternité de la matière. $^{52}$

At least one author attributed the success of the dinners of the baron $\mathrm{d}^{\prime} \mathrm{Holbach}$ to the inconspicuous role of his wife. Morellet informs us that not only did Mme d'Holbach not attempt to interfere with conversations, but also that she usually sat in the corner without saying anything or, at best, allowed herself to talk in a low voice with some of her intimates. ${ }^{53}$ In contrast, the dinners with Helvétius, gathering almost the same company as d'Holbach's, were less satisfactory than those of the baron. According to Morellet, Helvétius's wife was chiefly to blame: not only did she interfere with the choice of guests by preventing those she did not like from being invited, but she also stirred disorder into philosophical discussions in which she could not help engaging herself. ${ }^{54}$

The major line of the criticism of salons in the second half of the eighteenth century was their emphasis on decorum and propriety - the very qualities highly praised in the previous century. Polite conversation seemed to have outlived its usefulness and began to be felt as a straightjacket, rather than as a civilizing experience and a polish necessary for social advancement. While in the seventeenth century polite conversation

51 See Daniel Roche, Les Républicains des Lettres: Gens de culture et Lumières au XVIII siècle (Paris: Fayard, 1988), 247; Alan Charles Kors, D'Holbach Coterie. An Enlightenment in Paris (Princeton, New Jersey: Princeton University Press, 1976).

52 Letter of 2 December 1765 to Georges Selwin, as quoted by Feuillet de Conches, Les Salons de conversation au dix-huitième siècle (Paris: Charavay Frères, 1882), 71.

53 Morellet, Mémoires inédits, 141.

54 Ibid. 
was expected to be an exercise in form and an art of sophisticated pleasing, eighteenth-century critics thought that the emphasis on form in politeconversation inhibited meaningful communication. The concern with content rather than with form in verbal communication became an increasingly important issue in the eighteenth century and it was a change in emphasis from form to content that led to the change in the valorization of polite conversation, and eventually to the criticism of salons.

Some authors argued that polite conversation was inappropriate for dealing with matters of public concern and was actually detrimental to any serious debate. This was the argument used by Morellet in his polemical exchange with the abbé Ferdinando Galiani (1728-1787) over the French government's grain trade policy in the 1770s. In the pamphlet Dialogues sur le commerce des blés published in 1769, Galiani argued against the liberalization of the grain trade policy advocated by the physiocrats and instituted by the government. In response, Galiani was attacked by the physiocrats and by his long-time friend Morellet who defended the government's liberal policy. ${ }^{55}$ The Galiani-Morellet dispute was not only a clash of two conflicting views on the grain trade policy, but also a clash of two opposite modes of communication. One, represented by Galiani, was based on the ideal of polite conversation; the other, represented by Morellet, emphasized the substance of the issue, with no particular consideration given to a polite tone. Galiani's pamphlet was constructed as a series of leisurely conversations among three characters, very much in the style of seventeenth-century conversational works meant to entertain and educate polite society, such as the genre of the science du monde represented by the Entretiens sur la pluralité des mondes by Fontenelle (1657-1757). ${ }^{56}$ In contrast, Morellet's refutation of Galiani was written as a formal treatise, the kind which would be dismissed by seventeenth-century polite society as pedantic and savant. Galiani's and Morellet's works also differed in the tone assumed by each author. While Galiani's was light and relaxed, even humorous at times, and meant to entertain his readers, Morellet's was serious and focussed

55 André Morellet, Réfutation de l'ouvrage qui a pour titre 'Dialogues sur le commerce des blés' (London: n.p., 1770).

56 Huguette Cohen claims that Galiani's dialogues differed from Fontenelle's in that Galiani's 'were a clash of characters with utterly distinctive personality traits.' ('Diderot's Machiavellian Harlequin: Ferdinando Galiani,' Studies on Voltaire and the Eighteenth Century 256 (1988), 136). For the present discussion this difference is less important than the similarities, particularly the idea of modeling written dialogues upon polite conversation that does not lead to controversy. 
upon developing his argument, with no digressions or attempts to entertain. Polite discourse - argued Morellet - presented falsehoods wrapped up in seductive colours, made people seek entertainment and not the truth, was unnecessarily convoluted and made his argument difficult to follow. In short, the form obscured the content. Furthermore, politeness had moral implications. Morellet pointed out the ambiguous relationship between politeness and authority: politeness, he argued, reinforced the existing power structures and hierarchies. Politeness as promoted by Galiani concealed rather than revealed reality.

Morellet, of course, was not the first author in the eighteenth century who pointed out the intellectual and moral implications of politeness. In his Essai sur la société des gens de lettres et des grands, sur la réputation, sur les mécènes, et sur les récompenses littéraires (1752) D'Alembert wrote about the debilitating influence of politeness and advocated the independence of writers from polite society. Politeness could inhibit free intellectual activity because in order to make philosophy and science more accessible, it subjected them to the trivial laws of decorum. ${ }^{57}$ Politeness could hamper sincerity and encourage flattery, thus reducing conversation to an exchange of commonplaces. This line of criticism was expressed, for example, by François-Vincent Toussaint in Les Mours (1750) and Charles Pinot Duclos in Considérations sur les mœurs de ce siècle (1751) ${ }^{58}$ Later in the century, in an essay read before the Académie française in 1785, Marmontel denounced the notion of bon usage established by the court and le monde, 'whose language turns on a small number of words, most vague and confused, with equivocal or half-veiled senses, as is suitable to politeness, dissimulation, extreme reserve, light jesting, refined malice, or skillful flattery. ${ }^{59}$

According to Jean-Jacques Rousseau (1712-1778), one of the most vocal critics of Old-Regime mondanité, the salon was the very place where the intellectual and moral implications of politeness revealed themselves

57 About the tensions between the discourse used by scientists and philosophers and by polite society in Old-Regime France, see Peter France, Rhetoric and Truth in France. Descartes to Diderot (Oxford: Clarendon Press, 1972), 76-78.

See Peter France, Politeness and its Discontents: Problems in French Classical Culture (Cambridge: Cambridge University Press, 1992), 68-69. Peter France writes that Duclos' writings suggested the need for a new kind of politeness, less exclusive and more compatible with civic virtue. 'The latter would no longer be located in the court or the salon, but in a place where citizens might meet,' ibid., 69 .

59 Marmontel, De l'autorité de l'usage sur la langue, 19; as quoted by Rosenfeld, A Revolution in Language, 84. 
because it was a place where gens de lettres intermingled with polite society. Politeness cultivated by women in salons required reciprocity and made men similar to women; it effeminated men and deprived them of their manly virtue, thus it became the source of corruption for the whole nation. ${ }^{60}$ In one of his first publications in the early 1750 s, the Discours sur les sciences et les arts, Rousseau launched an attack on the debilitating effect of politeness in the salons:

Aujourd'hui que des recherches plus subtiles et un goût plus fin ont réduit l'Art de plaire en principes, il régne dans nos mœurs une vile et trompeuse uniformité, et tous les esprits semblent avoir été jettés dans un même moule: sans cesse la politesse exige, la bienséanse ordonne: sans cesse on suit des usages, jamais son propre génie. On n'ose plus paroitre ce qu'on est; et dans cette contraine perpétuelle, les hommes qui forment ce troupeau qu'on appelle société, placés dans les mêmes circonstances, feront tous les mêmes choses si des motifs plus puissans ne les en détournent. ${ }^{61}$

Similarly, Rousseau's Lettre à Monsieur d'Alembert sur les spectacles (1758) was in fact an attack on the sociability of polite society, with its falsity, flattery and disguise. Salon conversation epitomized all the vices of politeness, as Rousseau stated in his Julie, ou La Nouvelle Héloïse (1761).

Mais au fond que penses-tu qu' on apprenne dans ces conversations si charmantes? A juger sainement des choses du monde? à bien user de la société, à connaître au moins les gens avec qui l'on vit? Rien de tout cela ... On y apprend à plaider avec art la cause du mensonge, à ébranler à force de philosophie tous les principes de la vertu, à colorer de sophismes subtils ses passions et ses préjugés, et à donner à l'erreur un certain tour à la mode selon les maximes du jour. Il n'est point nécessaire de connoitre le caractère des gens, mais seulement leurs intérets, pour deviner à peu près ce qu'ils diront de chaque chose. ${ }^{62}$

Eighteenth-century criticism of salon conversation was in effect a criticism of mondanité - it not only indicated the changing expectations from

60 Peter France noted that of the two faces of politesse, the former dominated: it was difficult to separate it from its association with the Old Regime. See, Politeness and its Discontents, $59 \mathrm{ff}$.

61 Discours sur les sciences et les arts, in Jean-Jacques Rousseau, CEuvres complètes, ed. Bernard Gagnebin and Marcel Raymond, 5 vols. (Paris: Gallimard, 1959-1995), III, 8.

62 Julie, ou la Nouvelle Héloise, 2nd part, Letter XIV, in CEuvres complètes, II, 233. 
verbal forms of communication but also the changing value of politeness. By performing their roles as guardians of politeness and decorum, salonnières in the eighteenth century found themselves in an uneasy position as politeness acquired an increasingly ambiguous connotation.

The reaction against the theatricality of salons and the culture of mondanité in general was grafted into debates with wider ramifications. For example, the quest for authenticity, simplicity, the natural over the artificial, and content over form belonged to the reaction that occurred in France in the mid-eighteenth century against classical aesthetic theory based on the idea that aesthetic fiction is a privileged means of attaining the truth. In his Lettre à d'Alembert sur les spectacles, Rousseau attacked the classical aesthetic theory and presented his quest for authenticity, simplicity, the natural over the artificial, and content over form. Similarly, Diderot argued for naturalness in his criticism of the artifice of French theatre and its lack of reality. The critique of classical aesthetic theory was extended to the realm of ethics. The new art, based on 'nature' - along with related concepts of simplicity and authenticity - was to purify manners and society's mours. The wave of sensibilité which reached nearly epidemic proportions between the death of Rousseau (1778) and the Directory (1795-1799) reflected these new aesthetic and ethical orientations. Similarly, the quest for perfect communication became a distinctive theme in the eighteenth century and expressed itself in works of fiction, especially fictitious travel accounts, in the interest in gestural language and in speculation on the origins of language ${ }^{63}$ Criticism of polite conversation expressed a concern for functional, directly communicative gesture that also pervaded these debates.

The seventeenth-century mondanité, once a monolithic and all-encompassing system of public conventions and rules which required conformity and the subordination of individual impulse to collective ordering, began to crack before the Old Regime was over. Social life in Paris during the years preceding the outbreak of the French Revolution split into a number of specialized societies and discrete interest groups with different backgrounds and different ideas about sociability. The dinners of $\mathrm{d}^{\prime}$ Holbach and Helvétius already signaled the forthcoming fragmentation of social life. From the 1770s, new forms of sociability emerged that had little to do with mondanité: musées, lycées and clubs catering primarily to men. As one nineteenth-century author put it, 'Throughout Paris, there were nothing but Clubs, Sociétés, Lycées, Musées. These circles, in 
which hardly anyone but men assembled, dethroned the salons where until that time, women had reigned. ${ }^{64}$ In contrast to salons focussed on polite conversation that had no real significance, there appears to have been no room in this sociability for the elements that did not perform a clearly discernible function or for anything resembling Old-Regime mondanité. Louis Sébastien Mercier (1740-1814) wrote in his Tableau de Paris (1781-1788) that this new sociability satisfied the need for a direct, unmediated and unambiguous communication.

Le goût des cercles, inconnu de nos pères, et copié des Anglais, a commencé à se naturaliser à Paris. Dans ces sortes d'assemblées, on s'instruit en s'amusant; l'histoire, la physique, la poésie, s'y donnent la main; c'est une espèce d'académie composée de personnes de tout état, où le goût de toutes les sciences et de tous les arts y fait un heureux mélange, qui doit contribuer à leur progrès. ${ }^{65}$

The fragmentation of social life in late eighteenth-century Paris heralded the end of the culture of mondanité. The French Revolution dealt the fatal blow to Old-Regime mondanité for although the salon as a form of sociability survived the upheaval, the Old-Regime notion of le monde did not. In the fragmented and factionalized social world of post-Revolutionary France no clear norm or clear, undisputed image of le monde with claims to absolute authority would govern the public consciousness.

JOLANTA T. PEKACZ

Dalhousie University

64 Félix Rocquain, L'Esprit révolutionnaire avant la Révolution, 1715-1789 (Paris, 1878), 415; as quoted in Dena Goodman, The Republic of Letters. A Cultural History of the French Enlightenment (Ithaca and London: Cornell University Press, 1994), 240-241.

65 Louis Sébastien Mercier, Tableau de Paris in Paris le jour, Paris la nuit, ed. Michel Delon and Daniel Baruch (Paris: Robert Laffont, 1990), 316. 